\title{
Analysis of Purchase Decision and its Impacts towards Honda Beat Motorcycle's Customer Satisfaction Viewed through Product Quality and Price Perception Variables at Tangerang City Area
}

\author{
Christianto Hadisiswanto Putro \\ Master of Management, Mercu Buana University \\ Jakarta, Indonesia
}

\begin{abstract}
The purpose of this research is to explore the impacts of product quality and price perception against purchase decision for Honda Beat motorcycle's customer satisfaction at Tangerang City Area. This research type used purposive research, whereas data analysis method used Structural Equation Modeling (SEM) with the Lisrel (Linear Structural Relations) program. The Population were community of Honda Beat's users at Tangerang City with 215 respondents sampled. The results showed that 1) product quality has positive and strong impact over purchase decisions, 2) price perception has positive and strong impact over purchase decision, 3) purchase decision has positive and strong impact over customer satisfaction, 4) product quality has positive and significant impact to customer satisfaction and 5) price perception has positive and significant influence over customer satisfaction.
\end{abstract}

Keywords:- Product Quality, Price Perception, Purchase Decision, Customer Satisfaction.

\author{
Adi Nurmahdi \\ Lecturer of Postgraduate, Mercu Buana University \\ Jakarta, Indonesia
}

\section{INTRODUCTION}

The growth of automotive industry in Indonesia currently have developed rapidly. It is because the needs and demands from public to adequate transportation facilities are high. Until now the motorcycle sales in Indonesia reached 7 million units per year. Motorcycle sales in Indonesia were said to be the highest compared to other ASEAN countries. That is because motorcycle sales and production in Indonesia did not yet found its optimum production point, and consequently as for motorcycle sales, it cannot be stop because it is a necessity as well as the lifestyle of public community.

Honda is motorcycle manufacturer from Japan which since 1971 has always became a pioneer in motorcycle industry in Indonesia. Based on (Triatmono.info, 2018) Honda motorcycle sales won first ranks with total sales were $4,759,202$. Furthermore, second place was Yamaha with total sales of 1,455,088 and next was Suzuki at 89,508 then Kawasaki at 78,892 and last on list was TVS at 331.

\begin{tabular}{|c|c|c|c|c|c|c|}
\hline Period & Honda & Yamaha & Suzuki & Kawasaki & TVS & Total \\
\hline Jan-2018 & 345.957 & 122.989 & 6.051 & 7.509 & 31 & 482.537 \\
\hline Feb-2018 & 339.152 & 85.429 & 4.500 & 10.456 & 49 & 439.586 \\
\hline Mar-2018 & 384.187 & 133.126 & 4.077 & 13.969 & 12 & 535.371 \\
\hline Apr-2018 & 458.499 & 113.182 & 6.954 & 2.282 & 4 & 580.921 \\
\hline May-2018 & 436.727 & 140.068 & 7.663 & 4.828 & 18 & 589.304 \\
\hline Jun-2018 & 271.206 & 96.150 & 5.357 & 2.302 & 19 & 375.034 \\
\hline Jul-2018 & 450.622 & 127.101 & 8.639 & 7.366 & 21 & 593.749 \\
\hline Aug-2018 & 443.694 & 108.896 & 8.355 & 7.016 & 95 & 568.056 \\
\hline Sep-2018 & 406.841 & 134.419 & 9.371 & 7.036 & 25 & 557.692 \\
\hline Oct-2018 & 456.582 & 138.012 & 10.489 & 5.212 & 27 & 610.322 \\
\hline Nov-2018 & 440.659 & 140.683 & 10.002 & 6.003 & 17 & 597.364 \\
\hline Dec-2018 & 325.076 & 115.033 & 8.050 & 5.003 & 19 & 453.181 \\
\hline Total & 4.759 .202 & 1.455 .088 & 89.508 & 78.892 & 331 & 6.383 .111 \\
\hline
\end{tabular}

Table 1: - Motorcycle Sales Data for 2018

Source: www.triatmono.info (2019)

Honda quite dominates the motorcycle sales market due to large public trust in Honda motorcycles. Besides that, Honda has 29 main dealers throughout Indonesia, 1814 outlets, 3619 workshops and 7550 spare part outlets. One of the biggest contributors to Honda's income each year is
Automatic motor type. Even today, automatic scooter type motorcycles (scooter) remain as the most favorite motorbike for Indonesian people. Based on data from Indonesian Motorcycle Industry Association, Honda scooter sold more 
than 3 million units or around $84.1 \%$ during 2018 period and it was dominated by Honda Beat.

Those increase in Honda Beat sales in Indonesia, especially in Tangerang City was influenced by several factors such as product quality and price perception. With the product quality and the good price perception offered by Honda Beat, it will be easy for customers to make purchase decision because they feel satisfied with what Honda Beat provided. And because of that the Honda Beat has an Enhanced Smart Power (ESP) which serves to increase fuels efficiency and reduce wasted energy so it will produce fuel efficiency and higher vehicle performance when riding. Whereas the Yamaha Mio and Suzuki Nex are not equipped with ESP, therefore Honda Beat has advantages in terms of engine type. Honda Beat's buying price is cheaper than Yamaha Mio but still higher than Suzuki Nex. Although Honda Beat's purchase price is higher than Suzuki Nex, when it is resold Honda has better selling value compared to Suzuki Nex and Yamaha Mio. That is because Honda Beat engine specifications are more superior than competitors on its class.

\begin{tabular}{|l|c|c|c|}
\hline \multicolumn{1}{|c|}{ Specifications } & Honda Beat & Yamaha Mio & Suzuki Nex II \\
\hline Main Type & $\begin{array}{c}4-\text { Stroke, SOHC with air } \\
\text { conditioning, ESP }\end{array}$ & $\begin{array}{c}\text { 4 Stroke, SOHC with air } \\
\text { conditioning }\end{array}$ & $\begin{array}{c}4 \text { Stroke, SOHC with air } \\
\text { conditioning }\end{array}$ \\
\hline Cylinder Capacity & $110 \mathrm{cc}$ & $125 \mathrm{cc}$ & $113 \mathrm{CC}$ \\
\hline Transmission System & V-Matic & CVT Otomatis & CVT \\
\hline Lenght x Width x Height & $1856 \times 666 \times 1068 \mathrm{~mm}$ & $1870 \times 685 \times 1035 \mathrm{~mm}$ & $1890 \times 675 \times 1045 \mathrm{~mm}$ \\
\hline Fuel Consumptions & $73.5 \mathrm{Km} / \mathrm{Liter}$ & $60.3 \mathrm{Km} / \mathrm{Liter}$ & $82.6 \mathrm{Km} / \mathrm{Liter}$ \\
\hline Price & $\mathrm{Rp} 15.000 .000$ & $\mathrm{Rp} 15.550 .000$ & $\mathrm{Rp} 13.950 .000$ \\
\hline
\end{tabular}

Table 2: - Comparison of Specifications between Honda Beat, Yamaha Mio, Suzuki Nex II Source: www.semisena.com (2019)

Based on those background above, the author would like to examine further about how to improve those purchase decisions and their impact on customer satisfaction through this research with the title "Analysis Over Purchase Decision and its Impacts Towards Honda Beat Motorcycle's Customer Satisfaction Viewed Through Product Quality and Price Perception Variables at Tangerang City Area".

\section{THEORITICAL REVIEW}

\section{A. Product Quality}

Based on Schiffman and Kanuk in Gulliando and Basri (2019) stated that product quality is an ability from company to provide an identity or feature on each products so consumers would recognize as theirs. According to Kotler and Armstrong (2014: 229) which defined product quality as characteristic from product or service which provides ability to fill customer needs. Lastly on list these statement from Nasution (2005) which states that product quality is dynamic condition related to products, people / labor, processes and tasks, as well as the environment that could meets or exceeds those consumer expectations.

\section{B. Price Perception}

According to Campbell in Cockrill and Goode (2010: 368) which stated that those prices perceptions is a psychological factor in various aspects which have an important influence against consumer reactions to prices. And according to Peter and Olson in Muharam and Soliha (2017) price perception is how price information could be understood entirely by consumers and gives the meaning to them. Based on Schiffman and Kanuk in Hermawan, et.al. (2017) price perception is how consumers see prices as high, low and fair prices.

\section{Purchase Decision}

Based on Kotler and Armstrong (2014) a purchase decision is the stage of decision making process where consumers would actually buy. According to Peter and Olson in Muharam and Soliha (2017) purchase decisions is a process which combined those knowledges to evaluate two or more alternative acts and choose one of them.

\section{Customer Satisfaction}

Based on Kotler and Armstrong (2014:150) customer satisfaction is pleasure feeling or disappointment which arises after comparing the performance (results) of products thought to the expected performance (or results). Meanwhile according to Yazid in Kurniawan, et. al. (2020) customer satisfaction is the differentiate between the expectations they have and the performance they actually received. If expectations are high, while the performance is so so then those satisfactions cannot be achieved. Furthermore, Kotler and Armstrong (2008) in Gunawan and Prasetyo (2020) said that customers created expectations regarding the value and satisfaction that given from various market offers and buy based on those expectations.

\section{E. Prior Research}

Nur and Welsa (2017) research results show that product quality does not influence purchasing decisions. While research by Ali et. al., (2018) shows that product quality has significant and positive influence over purchase decision.

The results from Pardede and Haryadi's (2017) research show that price perception has no positive and strong reaction over customer's purchase decisions. While the results from Ali, et. al., (2018) shows that price perception variable partially and simultaneously has significant and positive influence towards purchase decisions. 
Nur and Welsa (2017) research results showed that purchase decisions do not influence customer satisfaction. In conversely the research results from Nur and Shihab (2018) was described that purchase decision variable has strong influence against customer satisfaction.

Research by Unggul and Adiwibowo (2018) showed that product quality has no impact towards customer satisfaction. However, the results of Suhendar and Ruswanti's research (2019) showed that product quality has an impacts over customer satisfaction.
The research results of Hermawan, et. al. (2017) illustrated that price perception has an influences to customer satisfaction. It does similiar with research results from Hariani and Sabar (2019) which shows that price perception has positive and strong reaction against customer satisfaction.

\section{F. Theoretical Framework}

Based on the links between variables that have been stated, the theoretical framework of this research could be seen in figure below.

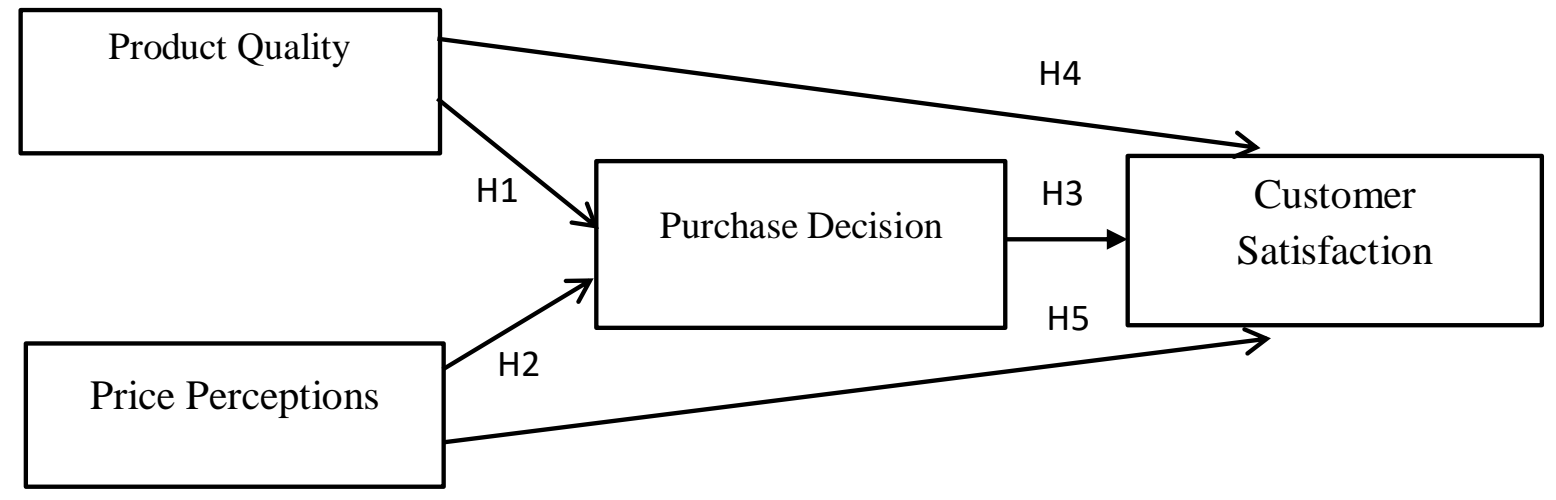

Fig. 1: - Theoretical Framework

\section{G. Hypothesis}

According to theoretical framework above, the hypothesis in this research could be form as in below:

$\mathrm{H1}$ : Product quality has positive and strong reaction over purchase decisions.

$\mathrm{H} 2$ : Price perception has positive and strong influence on purchase decisions.

H3: Purchase decision has positive and remarkable impact to Customer satisfaction.

H4: Product quality has positive and crucial effect against customer satisfaction.

H5: Price perception has positive and exceptional influence towards customer satisfaction.

\section{METHODOLOGY}

Type of research was conclusive research which used to support decision makers in finding, evaluating and choosing series of an actions that must be taken in certain situations. Exogenous variables consisted of product quality and price perception. The intervening variable is the purchase decision while Endogenous variables for this research is customer decisions.

Those variables measured in this research using Likert scale. Data analysis techniques used Structural Equation Modeling (SEM) which assisted by the Lisrel (Linear
Structural Relations) program version 8.80. The reason for adding SEM method in this research is because SEM could examine those theories by testing suitability of model with data and allows a variable to act dynamically where variable can act as dependent variable and also as independent variable on a model.

The population used were community of Honda Beat's customers at Tangerang City. The sample sized was discovered based on the data analysis method to be used. The guideline is 5-10 times from the number of indicators to all variables (Hair in Ferdinand, 2005). Based on these guidelines, the number of samples in this research were $5 \mathrm{x}$ $43=215$ respondents. The sampling technique used nonprobability sampling technique alongside with convenience sampling technique.

\section{RESULTS AND DISCUSSIONS}

\section{A. Demographic Characteristics of Respondents}

Based on the characteristics from 215 respondents who are community of Honda Beat's users in Tangerang City Area, it could tell that the majority of Honda Beat users are women $(59.07 \%)$ aged between $40-50$ years $(45.12 \%)$ who have a bachelor's degree $(26.98 \%)$ and work as employees (26.04). So it could be said that Honda Beat users are women who work at offices and have high mobility. 
ISSN No:-2456-2165

\begin{tabular}{|c|c|c|c|}
\hline No. & Description & Frequency (Person) & Percentage (\%) \\
\hline \multirow{3}{*}{1} & Gender & & \\
\hline & - Male & 88 & 40.93 \\
\hline & - Female & 127 & 59.07 \\
\hline \multirow{5}{*}{2} & Ages & & \\
\hline & $21-25$ years & 35 & 16.28 \\
\hline & $26-40$ years & 37 & 17.21 \\
\hline & $40-50$ years & 97 & 45.12 \\
\hline & $>50$ years & 46 & 21.4 \\
\hline \multirow{6}{*}{3} & Last Education & & \\
\hline & SMA & 43 & 20.00 \\
\hline & D3 & 36 & 16.74 \\
\hline & S1 & 58 & 26.98 \\
\hline & $>\mathrm{S} 2$ & 45 & 20.93 \\
\hline & Others & 33 & 15.35 \\
\hline \multirow{5}{*}{4} & Job Status & & \\
\hline & Student & 46 & 21.40 \\
\hline & Employee & 56 & 26.04 \\
\hline & Entrepreneur & 59 & 27.44 \\
\hline & Others & 54 & 25.12 \\
\hline
\end{tabular}

Table 3: - Demographic Characteristics of Respondents

\section{B. Structural Fit Model Analysis}

The test results show that all indicators of product quality variables have loading factors $>0.50$, therefore it said that the latent variables of product quality meet the validity requirements. Likewise, with the results of product quality reliability test results in good reliability values where the results of the Construct Reliability $(\mathrm{CR})$ value $=0.974>$ 0.7, and the Variance Extracted (VE) value of $0.632>0.50$ so the product quality variable does meet the requirements of reliability as well.

\begin{tabular}{|c|c|c|c|c|c|}
\hline \multirow{2}{*}{$\begin{array}{c}\text { Indicator } \\
\text { Code }\end{array}$} & \multirow{2}{*}{ SLF } & \multirow{2}{*}{$\begin{array}{c}\text { Standard } \\
\text { Errors }\end{array}$} & \multicolumn{2}{|c|}{ Reliability } & \multirow{2}{*}{ Information } \\
\hline & & & $\mathrm{CR} \geq 0,70$ & $\mathrm{VE}>0,5$ & \\
\hline $\mathrm{X} 1.1$ & 0.78 & 0.44 & \multirow{24}{*}{0.974} & \multirow{24}{*}{0.632} & Valid \\
\hline $\mathrm{X} 1.2$ & 0.78 & 0.41 & & & Valid \\
\hline $\mathrm{X} 1.3$ & 0.78 & 0.41 & & & Valid \\
\hline $\mathrm{X} 1.4$ & 0.82 & 0.34 & & & Valid \\
\hline $\mathrm{X} 1.5$ & 0.76 & 0.43 & & & Valid \\
\hline $\mathrm{X} 1.6$ & 0.81 & 0.36 & & & Valid \\
\hline $\mathrm{X} 1.7$ & 0.84 & 0.33 & & & Valid \\
\hline $\mathrm{X} 1.8$ & 0.80 & 0.43 & & & Valid \\
\hline X1.9 & 0.82 & 0.43 & & & Valid \\
\hline $\mathrm{X} 1.10$ & 0.85 & 0.29 & & & Valid \\
\hline $\mathrm{X} 1.11$ & 0.85 & 0.30 & & & Valid \\
\hline $\mathrm{X} 1.12$ & 0.81 & 0.41 & & & Valid \\
\hline $\mathrm{X} 1.13$ & 0.86 & 0.31 & & & Valid \\
\hline $\mathrm{X} 1.14$ & 0.82 & 0.44 & & & Valid \\
\hline $\mathrm{X} 1.15$ & 0.85 & 0.35 & & & Valid \\
\hline $\mathrm{X} 1.16$ & 0.84 & 0.38 & & & Valid \\
\hline $\mathrm{X} 1.17$ & 0.82 & 0.39 & & & Valid \\
\hline $\mathrm{X} 1.18$ & 0.84 & 0.35 & & & Valid \\
\hline $\mathrm{X} 1.19$ & 0.83 & 0.38 & & & Valid \\
\hline $\mathrm{X} 1.20$ & 0.81 & 0.45 & & & Valid \\
\hline $\mathrm{X} 1.21$ & 0.81 & 0.39 & & & Valid \\
\hline $\mathrm{X} 1.22$ & 0.82 & 0.42 & & & Valid \\
\hline $\mathrm{X} 1.23$ & 0.83 & 0.41 & & & Valid \\
\hline $\mathrm{X} 1.24$ & 0.79 & 0.49 & & & Valid \\
\hline
\end{tabular}

Table 4: - Test Results of Validity and Reliability of Product Quality Variables
The test results show that all indicators of price perception variables have loading factors $>0.50$, Therefore the latent variables of price perception meet the validity requirements. Likewise, with the results of price perception variable reliability test results in good reliability values where the results of the Construct Reliability (CR) value $=$ $0.88>0.7$ and the Variance Extracted (VE) value of $0.56>$ 0.50 means that price perception variable also met with reliability requirements.

\begin{tabular}{|c|c|c|c|c|c|}
\hline \multirow{2}{*}{$\begin{array}{c}\text { Indicator } \\
\text { Code }\end{array}$} & \multirow{2}{*}{ SLF } & \multirow{2}{*}{$\begin{array}{c}\text { Standard } \\
\text { Errors }\end{array}$} & \multicolumn{2}{|c|}{ Reliability } & \multirow{2}{*}{ Information } \\
\hline & & & $\mathrm{CR} \geq 0, \mathbf{7 0}$ & $\mathrm{VE} \geq 0,5$ & \\
\hline $\mathrm{X} 2.1$ & 0.81 & 0.31 & \multirow{6}{*}{0.88} & \multirow{6}{*}{0.56} & Valid \\
\hline $\mathrm{X} 2.2$ & 0.82 & 0.40 & & & Valid \\
\hline $\mathrm{X} 2.3$ & 0.72 & 0.53 & & & Valid \\
\hline $\mathrm{X} 2.4$ & 0.74 & 0.62 & & & Valid \\
\hline $\mathrm{X} 2.5$ & 0.86 & 0.37 & & & Valid \\
\hline $\mathrm{X} 2.6$ & 0.71 & 0.65 & & & Valid \\
\hline
\end{tabular}

Table 5: - Test Results of Validity and Reliability of Price Perception Variables

The test results show all indicators of purchase decision variable has loading factor value $>0.50$ thus the latent variables of purchase decision meet validity requirements. It does Similarly with the results of reliability test of purchase decision variables produce good reliability values where the results value of Construct Reliability (CR) $=0.92>0.7$ and the Variance Extracted $(\mathrm{VE})$ value of $0.55>$ 0.50 means that purchase decision variable does met the reliability requirements. 
ISSN No:-2456-2165

\begin{tabular}{|c|c|c|c|c|c|}
\hline \multirow{2}{*}{$\begin{array}{c}\text { Indicator } \\
\text { Code }\end{array}$} & \multirow{2}{*}{ SLF } & \multirow{2}{*}{$\begin{array}{c}\text { Standard } \\
\text { Errors }\end{array}$} & \multicolumn{2}{|c|}{ Reliability } & \multirow{2}{*}{ Information } \\
\hline & & & $\mathrm{CR} \geq \mathbf{0 , 7 0}$ & $\mathrm{VE}>0,5$ & \\
\hline Z.1 & 0.75 & 0.38 & \multirow{10}{*}{0.92} & \multirow{10}{*}{0.55} & Valid \\
\hline Z.2 & 0.77 & 0.42 & & & Valid \\
\hline$Z .3$ & 0.77 & 0.40 & & & Valid \\
\hline Z.4 & 0.85 & 0.26 & & & Valid \\
\hline Z.5 & 0.82 & 0.33 & & & Valid \\
\hline Z.6 & 0.79 & 0.44 & & & Valid \\
\hline$Z .7$ & 0.71 & 0.59 & & & Valid \\
\hline Z.8 & 0.70 & 0.63 & & & Valid \\
\hline Z.9 & 0.68 & 0.65 & & & Valid \\
\hline Z.10 & 0.74 & 0.58 & & & Valid \\
\hline
\end{tabular}

Table 6: - Test Results of Validity and Reliability of

Purchase Decision Variables

The test results show that all indicators of customer satisfaction variables have loading factors $>0.50$, thus it could be said that customer satisfaction meet the validity requirements. Likewise, with the reliability test results of customer satisfaction variables created good reliability values where the value result of Construct Reliability $(\mathrm{CR})=$ $0.8>0.7$ and Variance Extracted (VE) value of $0.57>0.50$ meaning that customer satisfaction variable also meets reliability requirements.

\begin{tabular}{|c|c|c|c|c|c|}
\hline \multirow{2}{*}{$\begin{array}{c}\text { Indicator } \\
\text { Code }\end{array}$} & \multirow{2}{*}{ SLF } & \multirow{2}{*}{$\begin{array}{c}\text { Standard } \\
\text { Errors }\end{array}$} & \multicolumn{2}{|c|}{ Reliability } & \multirow{2}{*}{ Information } \\
\hline & & & $\mathrm{CR} \geq \mathbf{0 , 7 0}$ & $V E>0,5$ & \\
\hline Y.1 & 0.77 & 0.43 & \multirow{3}{*}{0.80} & \multirow{3}{*}{0.57} & Valid \\
\hline Y.2 & 0.84 & 0.39 & & & Valid \\
\hline Y.3 & 0.76 & 0.62 & & & Valid \\
\hline
\end{tabular}

Table 7: - Test Results of Validity and Reliability of Customer Satisfaction Variables

\section{Structural Fit Model Analysis and Tests}

This overall model compatibility test was performed to see how well the resulting model describes the actual conditions. Based on the results of the goodness of fit test, the equation model has fulfilled the requirements of absolute fit measure, incremental fit measure, and parsimonious fit measure as it shown in the table below.

\begin{tabular}{|c|c|c|c|c|}
\hline \multirow{2}{*}{ Goodness of Fit Size } & \multicolumn{2}{|c|}{ Match Size } & \multirow{2}{*}{\multicolumn{2}{|c|}{ Measurement Results }} \\
\hline & Good Fit & Marginal Fit & & \\
\hline Normed Chi-Square $\left(\chi^{2} / \mathrm{df}\right)$ & $<2.0$ & & 1.990 & Fit \\
\hline Root Mean Square Error (RMSEA) & $<0.08$ & & 0.069 & Fit \\
\hline Root Mean Square Residual (RMR) & $<0.05$ & & 0.043 & Fit \\
\hline Goodness of Fit Index (GFI) & $\geq 0.90$ & $0.70<0.90$ & 0.76 & Marginal Fit \\
\hline Normal Fit Index (NFI) & $\geq 0.90$ & $0.80-<0.90$ & 0.97 & Fit \\
\hline Non-Normed Fit Index (NNFI) & $\geq 0.90$ & $0.80-<0.90$ & 0.98 & Fit \\
\hline Comparative Fit Index (CFI) & $\geq 0.90$ & $0.80-<0.90$ & 0.98 & Fit \\
\hline Incremental Fit Index (IFI) & $\geq 0.90$ & $0.80-<0.90$ & 0.98 & Fit \\
\hline Relative Fit Index (RFI) & $\geq 0.90$ & $0.80-<0.90$ & 0.97 & Fit \\
\hline
\end{tabular}

Table 8: - Results of the Goodness of Fit Full Model test

From these test results which has been done and it could be seen that the coefficient of determination for dependent variable on purchase decision was 0.69 , meaning $69 \%$ of these variations that can be explained by independent variable such as product quality and price perception. While coefficient of determination for the dependent variable customer satisfaction was 0.92 means that $92 \%$ of these variations that could be explained by independent variable purchase decision, product quality, and price perception.

\section{Structural Equations}

Decision $=0.51^{*}$ Product $+0.38^{*}$ Price, Errorvar $,=0.33, R^{2}=0.69$
(0.10)
(0.10)
$(0.055)$
4.93
3.71
5.95

Satisfaction $=0.56^{*}$ Decision $+0.26^{*}$ Product $+0.19^{*}$ Price, Errorvar $,=0.085, R^{2}=0.92$

$\begin{array}{cccc}(0.085) & (0.089) & (0.089) & (0.032) \\ 6.62 & 2.94 & 2.11 & 2.62\end{array}$

Figure 2: - Structural Equation Model Output

\section{Hypothesis Examination}

By these results of hypothesis examination which found out the influence of product quality on purchase decisions can be illustrated with the value of t-values $=4.93$ $>1.96$. The coefficient value is positive which equal to 0.51 meaning that product quality variable has positive influence over purchase decision variable by $51 \%$. Therefore, the $\mathrm{H} 1$ hypothesis in this research which stated that product quality has strong influence against purchase decisions was accepted.

From these hypothesis test result regarding influence of price perception towards purchase decisions can be illustrated that the value of $\mathrm{t}$-value $=3.71$ which greater than $\mathrm{t}=1.96 .38 .0 \%$. Thus the $\mathrm{H} 2$ hypothesis which states that price perceptions have strongly effect on purchasing decision was accepted.

From these hypothesis test results whose tell about influence of purchasing decisions against customer satisfaction which could be seen that the value of t-value = 6.62 which greater than $t=1.96$ coefficient value is positive that is equal to 0.56 meaning that purchase decision variable 
has positive impact over customer satisfaction variables by $56.0 \%$. Therefore, $\mathrm{H} 3$ hypothesis in this research which stated that purchasing decisions has significantly influence to customer satisfaction was accepted.

From these hypothesis test result about influence of product quality against customer satisfaction which could be seen that the value of t-values $=2.94>1.96$. The coefficient value is positive that is equal to 0.26 meaning product quality variable has positive influence towards customer satisfaction variable by $26 \%$. Thus the $\mathrm{H} 4$ hypothesis which stated that product quality has strong impact over purchase decisions was accepted.

From these hypothesis test result about reaction from price perception to customer satisfaction which can be seen that value of $t$-value $=2.11$ is greater than $t=1.96$. The coefficient value is positive, that is 0.19 , meaning that price perception variable has positive impact over customer satisfaction variable of $19.0 \%$. Thus the H5 hypothesis which said that price perceptions significantly affect those customer satisfaction was accepted.

\begin{tabular}{|c|c|c|c|}
\hline Relationship Between Constructions & Estimates & T-Values & Information \\
\hline Product Quality-> Purchase Decision & 0.51 & 4.93 & Has Positive Influence and significant \\
\hline Price Perception -> Purchase Decision & 0.38 & 3.71 & Has Positive Influence and significant \\
\hline Product Quality-> Customer Satisfaction & 0.26 & 2.94 & Has Positive Influence and significant \\
\hline Price Perception-> Customer Satisfaction & 0.19 & 2.11 & Has Positive Influence and significant \\
\hline Purchase Decision -> Customer Satisfaction & 0.56 & 6.62 & Has Positive Influence and significant \\
\hline
\end{tabular}

Table 9:- Hypothesis Test Results

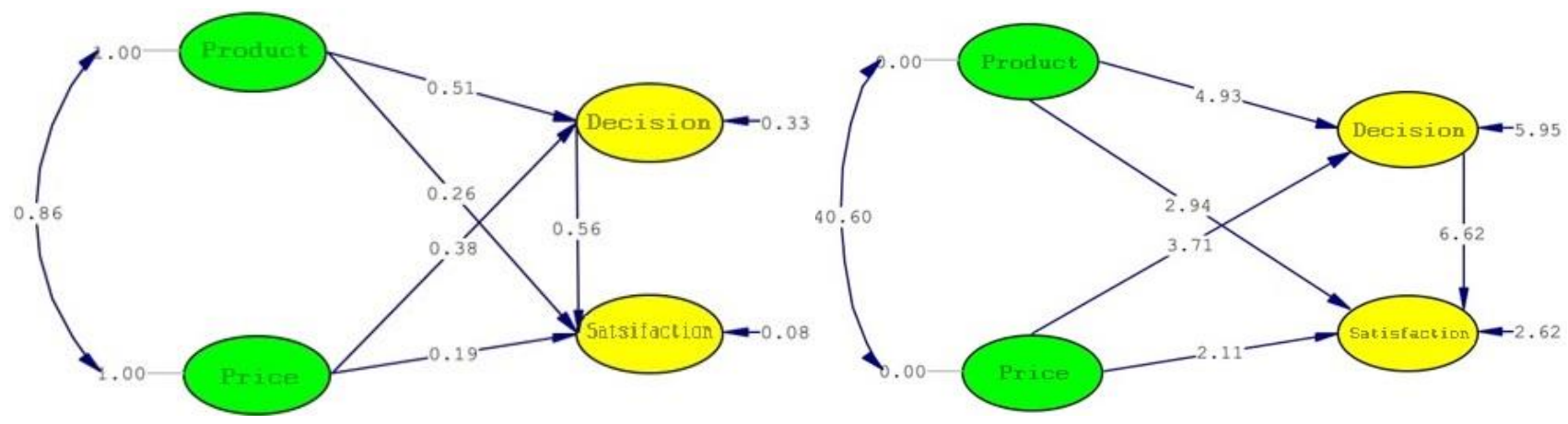

Fig. 3: - Estimates Structural Model and t-Value Structural Model

\section{E. Indirect Reactions Analysis}

Based on the indirect influence test result, it is known that value of $t$-Values $=4.14>1.96$. The coefficient value is positive with amount of $0.29(0.51 \times 0.56)$ meaning that Product Quality variable has positive reaction over Customer Satisfaction variable through Purchase Decision variable of $29 \%$. Thus indirect influence hypothesis in this research which stated that Product Quality has significant reaction over Customer Satisfaction through Purchasing Decisions was accepted.

Based on these indirect reaction test result, it is earned that value of $t$-Values $=3.39$ and greater than $t=1.96$ The coefficient value is positive that is equal to $0.21(0.38 \mathrm{x}$ 0.56) means that Price Perception variable has positive impact towards Customer Satisfaction variable through Purchase Decision variable (Z) of $21.0 \%$. Therefore, these indirect influence hypotheses in this research which stated that Price Perception has significant influence over Customer Satisfaction through Purchasing Decision was accepted.

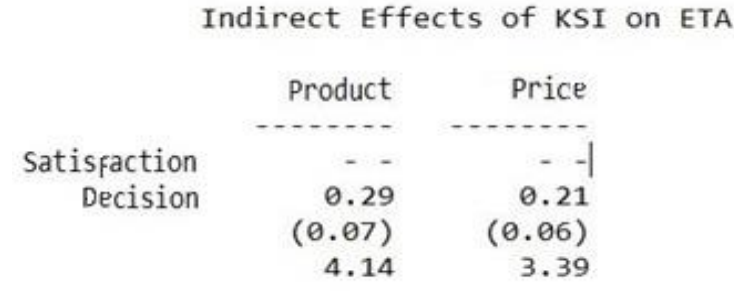

Fig. 4: - Indirect Influences test result

\section{F. Discussion}

The test results were described that product quality has positive and strong influence over Purchase Decision. The results from this research was confirmed also from the results of Ali, et. al., Research (2018) which shows that product quality has significant and positive impact against purchasing decisions. This illustrates that Honda Beat offered greatly impact to consumer's purchase decision, especially motorcycles which cannot be separated from the features offered by Honda Beat which set far above the other competitors. Therefore, the company should develop new innovation to improve the quality of Honda Beat products so customer will not switch heart and stay loyal to buy Honda Beat products. 
The test results were described that Price Perception has influenced positively and significantly towards Purchase Decision. These results were in line with research result from Ali, et. al., (2018) which stated that price perception has strong and positive influence over purchase decisions. This result was indicated that Price Perception is one of the factors which considered by automatic motor customers to make decision to buy, but with pricing strategy set by Honda Beat manufacturer is very appropriate, because of features and advantages that Honda Beat can offer / provided on products at lower price than its competitors.

The test results show that the Purchase Decision affects positively and significantly towards customer satisfaction. These results were also in line with results from Cahya and Shihab's research (2018) which stated that purchase decision variable has remarkable influence over customer satisfaction. This accordance with experience of Honda Beat consumers who have purchased these products and satisfied with products they bought, so they have a tendency to buy Honda Beat products again if there has products which fit with their characteristics and will even shares this experienced to their friends, relatives and communities that they followed.

The test results also show that product quality has positive and strong influence towards customer satisfaction. These results are in line with the results from Suhendar and Ruswanti research (2019) which tells that product quality has a reaction over customer satisfaction. This closely related to the expectations that wishes by customers. By these existences of this research shows that Honda Beat customers feel those expectations that they wanted are in accordance with products quality which offered / given by Honda Beat.

The test results were described that price perceptions have positively and significantly affect to customer satisfaction. The results of this research were also confirm from the research results by Hariani and Sabar (2019) and Hermawan, et. al., (2017) which stated that price perception was influenced those customer satisfactions. Which means that price perception that appears in customer's mind about Honda Beat is very satisfying. Honda Beat has a tendency to lowered prices so it would be more economical compared to other brands or competitors.

\section{CONCLUSION AND SUGGESTION}

\section{A. Conclusion}

According to the results, product quality has positive reaction over purchase decision, price perception has positive impact against purchase decision, while purchase decision has positive influence over customer satisfaction, likewise, with product quality which has positive influence over customer satisfaction, so do with price perception.

\section{B. Suggestion}

Good product quality will make the level of purchase decision over that product would increase accordingly, this could be done by the producer continuing to innovate and develop new products with more attractive appearances and in accordance to customer needs and improve features, reliability, and performance by increasing the ability of the suspension to be more comfort, which could increase maximum customers' satisfaction, and to achieve the desired satisfaction from Honda Beat customers.

Customer price perception will also increase Honda Beat purchase decision; this could be done from company by continuing to maintain affordable value for money prices to costumers. Because aside from the economical fuel consumption, price perception is one of the main advantages from Honda Beat when it compared to other automatic motorbike products.

Purchase decision made by the customer will be one of the measure towards Honda Beat's customer satisfaction. This could be done by the company with given product offers that could attract customers with competitive prices so customers will make product purchases because they were satisfied with the performance provided by Honda Beat products.

Product quality will have an impact towards Honda Beat's customer satisfaction which can be improved by conducting customer surveys of product components that need to be improved to meet with their expectations. From these results of the survey, the company will be able to make differentiation and product development better than before.

Price perception will also affect customer satisfaction by the company is expected to continue maintain the perception of prices who set by the company for Honda Beat products and provide additional bonuses such as helmets that have special characters based on customer's ages, or a functional and attractive jacket.

As for further research, it is expected to examine the other factors that could give such impact towards purchase decision and customer satisfaction such as brand image, promotion and service quality on products and other places with a wider range.

\section{REFERENCES}

[1] Ali, Hapzi., et. al., (2018). Model of Purchase Decision: Product Quality, Price, Promotion and Brand Awareness (Case Study of Teh Botol Sosro Products at Giant Mall Permata Tangerang). Scholars Journal of Art, Humanities and Social Sciences, 6(2): 487-498.

[2] Ali, Hapzi., et. al., (2018). Decision of Using Courier Service on PT Pos Indonesia: Analysis of Brand Image, Service Quality, and Perceived Price (Case Study: Fatmawati Post Office Cilandak, Jakarta Selatan). Scholars Journal of Economics, Business and Management, 5(2): 109-119.

[3] Cockrill, Antje., \& Goode, Mark M.H. (2010). Perceived Price and Price Decay in the DVD Marke. The Journal of Product and Brand Management, 19(5):367-374. 
[4] Gulliando, Diego,. \& Shihab, Muchsin S. (2019). The Effect of Product Quality, Price and Promotion on the Purchase Decision of Telkomsel Service Products. International Journal of Innovative Science and Research Technology, 4(9):419-425.

[5] Gunawan, Hendrik., \& Prasetyo, Johan Hendri. (2020). The Influence of Service Quality towards the Customer Satisfaction of XYZ Bank at Gajah Mada Branch Office in West Jakarta. International Journal of Innovative Science and Research Technology, 5(3):160-164.

[6] Hariani, Nita Kartika., \& Sabar, Mudji. (2019). Effect of Brand Image, Price Perception and Service Quality towards Customers Satisfaction of Expedition Services of PT. Pos Indonesia. International Journal of Innovative Science and Research Technology, 4(9):451-457.

[7] Hermawan, Bambang, et. al., (2017). Effect of Service Quality and Price Perception on Corporate Image, Customer Satisfaction and Customer Loyalty among Mobile Telecommunication Services Provider. International Journal of Management \& Social Sciences, 08(01):62-73.

[8] Kotler, Philip. \& Armstrong, Gary. (2014). Principles of Marketing, $14^{\text {th }}$ Edition. United States of America: Person.

[9] Kurniawan, Muchammad Rizal, et. al., (2020). The reaction towards Customer Satisfaction through the Service Quality Variable at Foreign Private Banks in Jakarta Headquarter. International Journal of Innovative Science and Research Technology, 5(3):983-987.

[10] Muharam, Wifky., \& Soliha, Euis. (2017). Kualitas Produk, Citra Merek, Persepsi Harga dan Keputusan Pembelian Konsumen Honda Mobilio. SENDI-U3,755762.

[11] Nasution, M. N. (2005). Manajemen Mutu Terpadu: Total Quality Management, Edisi Kedua. Bogor: Ghalia Indonesia.

[12] Nur, Cahya \& Shihab, Muchin Saggaff. (2018). Pengaruh Persepsi Harga, Kualitas Produk Citra Merek dan Layanan Purna Jual terhadap Keputusan Pembelian dan I Dampaknya terhadap Kepuasan Pelanggan Smartphone ASUS Studi Kasus di PT Data Scrip. Journal of Entrepreneurship, Management and Industry, 1(1):34-46.

[13] Nur, Dianah. \& Welsa, Henny. (2017). Pengaruh Kualitas Produk dan Citra Merek Terhadap Keputusan Pembelian Smartphone Xiaomi Serta Dampaknya Pada Kepuasan Konsumen (Studi Kasus Pada Mahasiswa Fakultas Ekonomi Universitas Sarjanawiyata Tamansiswa). Jurnal Manajemen, 7(1):16-26.

[14] Pardede, Ratlan., \& Haryadi, Tarcicius Yudi. (2017). Pengaruh Persepsi Harga Dan Kualitas Produk Terhadap Keputusan Pembelian Konsumen Yang Dimediasi Kepuasan Konsumen. Journal of Business \& Applied Management,10(1):55-79.
[15] Suhendar, Ucu., \& Ruswanti, Endang. (2019). Effect of Product Quality, Perception of Price and Satisfaction to Customer Loyalty (Study On Agroindustrial Company in Indonesia). International Journal of Economics, Commerce and Management, VII (3):23-33.

[16] Unggul, Januarko Moehammad., \& Adiwibowo, Bugi Satrio. (2018). Effect Product Quality, Price Perception, Customer Satisfaction Batik Betawi Loyalty in Jakarta. Journal of Business and Management (IOSR-JBM), 20(8):01-07. 